\title{
STAROŻYTNE MIASTA W BASENIE MORZA ŚRÓDZIEMNEGO - W POSZUKIWANIU FORMY IDEALNEJ
}

Na obszarze Starego Świata miasta narodziły się w czterech regionach: dolina rzeki Huang He, dolina Indusu, Mezopotamia, dolina Nilu․ Tym samym łatwo zauważyć, że proces najstarszej urbanizacji przebiegał w dolinach wielkich rzek, a jego początek miał miejsce, ogólnie rzecz ujmując, w IV tysiącleciu p.n.e. Na każdym terenie przebiegał niezależnie, ale według identycznych zasad, bo czynniki miastotwórcze wszędzie były takie same. Od tego momentu miasto pod względem morfologii, czyli układu przestrzennego, rozwijało się dynamicznie i w ciągu następnych tysiącleci, aż po dziś, wypracowało wiele wzorów. Niektóre pozostały jedynie teoretycznymi modelami, inne zrealizowano w praktyce. Wydaje się całkiem uzasadniony pogląd, że najstarsze miasta, także śródziemnomorskie, rozwinęły się w sposób naturalny, bez wcześniejszej dokładnej koncepcji morfologicznej. Mimo to, rodzą się spore wątpliwości, gdy dokładniej przeanalizuje się miasta egipskie z Okresu Wczesnodynastycznego czy Starego Państwa. W tych przypadkach można bowiem dostrzec przejaw wczesnej myśli urbanistycznej. Miasto było zaplanowane pod względem formy układu przestrzennego, struktury społecznej jego mieszkańców, a nawet ich liczby. Pomimo tego, że dopiero z Grecji okresu klasycznego oraz później z czasów wczesnego cesarstwa rzymskiego istnieje zapis rozważań teoretycznych dotyczących idealnych układów przestrzennych i społecznych miasta, to można z wyników dotychczasowych badań archeologicznych wywnioskować, że funkcjonowały one już wcześniej, zwłaszcza w Egipcie, przed $\mathrm{V}$ wiekiem p.n.e.

Miasta egipskie i częściowo również mezopotamskie wyraźnie dążyły do stworzenia formy idealnej. W badaniach nad starożytną urbanistyką często ulega się pokusie oceny z perspektywy całej późniejszej wiedzy i doświadczenia. Często również na proces historyczny patrzy się przez pryzmat ewolucjonizmu - od prostego układu początkowego do rozbudowanego i udoskonalonego układu współczesnego. Nie zawsze takie założenie metodologiczne jest właściwe, nie zawsze też daje się wytłumaczyć dostępnym nauce materiałem

\footnotetext{
* Dr Przemysław Nowogórski - archeolog i historyk, specjalizujący się w archeologii i historii starożytnego Izraela (zwłaszcza okres rzymski) oraz początkach i rozwoju pisma alfabetycznego. E-mail: iz.betsaida@gmail.com.

1 Dla porządku należy przywołać teren Anatolii i tamtejsze osady z epoki neolitu, traktowane w nauce jako najwcześniejsze przejawy urbanizacji - Çatalhüyük, Hacilar oraz Jerycho w Palestynie. To ostatnie nadal uchodzi za najstarsze miasto świata; zob. P. Bieliński, Starożytny Bliski Wschód. Od poczatków gospodarki rolniczej do wprowadzenia pisma, Warszawa 1985, s. 40-44, 65-69, 282-284.
} 
badawczym. Kiedy mowa jest o mieście idealnym, zazwyczaj zbyt pochopnie łączy się je z pojęciem miasta utopijnego. Nakłada się bowiem perspektywy nowożytną i współczesną, które do starożytnego Bliskiego Wschodu zbytnio nie pasują. Bardziej daje się je zastosować w świecie grecko-rzymskim. Miasta Bliskiego Wschodu sprzed czasów Aleksandra Wielkiego dążyły do formy idealnej i ją osiągnęły. Z kolei urbanistyka grecka, klasyczna i hellenistyczna, oraz rzymska, wypracowały własne modele idealnego miasta. Mimo to, były one pod silnym wpływem osiągnięć bliskowschodnich, przede wszystkim egipskich. Na pierwszy rzut oka można zauważyć, że dla Egiptu układem idealnym był prostokątny lub najbardziej zbliżony do prostokąta obrys granic (murów) miasta i ulice biegnące równolegle do głównych linii murów, co sprawiało, że w wielu wypadkach krzyżowały się one pod kątem prostym. Powstał w ten sposób ortogonalny plan siatki ulic. Cecha ta wyróżniała plan hippodamejski, czyli grecki z V wieku p.n.e., znakomicie rozpowszechniony na Wschodzie hellenistycznym, u Etrusków i w wielu miastach rzymskich.

Hippodamos Milezyjczyk raczej nie wymyślił planu ortogonalnego, tylko przeniósł wzór egipski, prawdopodobnie znany w Jonii już przed nim. Ostatecznie, Grecy ściągnęli od Egipcjan wzorzec rzeźby pełnoplastycznej, mogli również zaczerpnąć od nich przestrzenne rozplanowanie miasta. Jednak to Hippodamos i późniejsi teoretycy rozwinęli w basenie Morza Śródziemnego tę formę morfologii miast. Warto zauważyć, że koncepcja urbanistyczna poszukująca układu idealnego mogła narodzić się jedynie na obszarach o wysokim poziomie rozwoju kulturowego oraz cywilizacyjnego. Tym samym miasto idealne było integralnym elementem wysokich osiągnięć cywilizacyjnych człowieka. I nie zmieniło się to do dziś!

Przedmiotem niniejszego opracowania jest dążenie urbanistyki starożytnej do wypracowania idealnej morfologii miasta. Dla omawianego regionu takim ideałem była ortogonalna siatka ulic. W niektórych przypadkach również prostokątny, a nawet zbliżony do kwadratu, obrys granic miasta. Ideał ten omawiam na najbardziej charakterystycznych i reprezentacyjnych przykładach miast śródziemnomorskich, co umożliwi ukazanie tego zagadnienia w sposób syntetyczny.

\section{Miasta Bliskiego Wschodu w dążeniu do idealnej morfologii}

Wypada rozpocząć od miast egipskich, czyli podstawowego wzorca idealnej morfologii miasta. O urbanistyce Doliny Nilu więcej wiadomo dopiero od stosunkowo niedługiego czasu. Materiał badawczy nie jest olbrzymi, ale pozwala na pewne ogólne wnioski. Pozwala też na podtrzymanie hipotezy o dążeniu do idealnego układu urbanistycznego zaplanowanego jako czworokąt, bardziej prostokąt niż kwadrat. Oczywiście, nie wszystkie miasta faraońskiego Egiptu reprezentowały taką linię obrysu murów. Spora grupa miast miała kształt owalny. Wynikało to zazwyczaj z uwarunkowań terenowych². Wspólną cechą były grube wysokie mury zbudowane z cegły. Proces urbanizacji Egiptu rozpoczął się z większym dynamizmem w Okresie Starego Państwa (2650-2I25 p.n.e.) $)^{3}$ Zapewne był kontynuacją wcześniejszego

\footnotetext{
2 Chociaż nawet tam, gdzie teren nie był zbyt sprzyjający regularnym układom przestrzennym, powstały one na planie czworoboku. Jako przykład może posłużyć twierdza w Szalfak koło II Katarakty w Nubii z czasów XII dynastii, por. G. A. Reisner, N. F. Wheeler, D. Dunham, Second Cataract Forts II. Uronarti, Shalfak, Mirgissa, Boston 1967, plan X.

3 Wszystkie daty odnoszące się do chronologii Egiptu po czasy Aleksandra Wielkiego stosuję tu wg The Oxford History of Ancient Egypt, red. I. Shaw, Oxford 2000.
} 
z czasów I i II dynastii (ok. 3000-2650 p.n.e.). Problem ten będzie można bardziej szczegółowo wyjaśnić dopiero w przyszłości, w miarę pozyskiwania nowych rezultatów badań archeologicznych.

Najlepszym przykładem wczesnego miasta o regularnym układzie przestrzennym jest Nechen (gr. Hierakonpolis; ob. Kom el-Ahmar) z czasów Starego Państwa. Miasto otaczał ceglany mur, nadający mu obrys nieregularnego czworoboku. Zachodni i południowy odcinki muru nie biegły równolegle do wschodniego i północnego. Przebieg ulic i zabudowa Nechen nie zostały dostatecznie przebadane, ale wydaje się, że wąskie uliczki w części północno-wschodniej biegły równolegle do muru północnego. Analogicznie ustawione były domy w tej części miasta. Natomiast ukierunkowanie domów i prawdopodobny przebieg uliczek w części południowej dostosowane zostały do usytuowania znajdującego się tu kompleksu świątynnego Horusa. Innymi słowy, sieć ulic i zabudowa reprezentowała tendencje morfologii regularnej.

Innym ciekawym przykładem regularnych układów na planie prostokąta są tzw. miasta piramid, czyli zamknięte osady przy piramidach z Okresu Starego Państwa. Jednak nie były to miasta w powszechnie przyjętym znaczeniu tego pojęcia ${ }^{4}$. Służyły bowiem czasowemu mieszkaniu w nich personelu świątynnego, sprawującego kult zmarłego króla lub królowej, oraz obsłudze logistycznej. Personel ten zmieniał się co miesiąc, więc ludzie ci musieli na stałe mieszkać poza miastami piramid. Z czasów Starego Państwa znanych jest obecnie kilka takich osiedli. Jedno z ciekawszych znajduje się przy grobowcu królowej Chentkaus I w Gizie ${ }^{5}$. To wąskie miasto mierzyło sto pięćdziesiąt metrów z zachodu na wschód i otaczał je gruby mur $(2,5 \mathrm{~m})$. Wzdłuż południowego boku biegła podwójna ulica, a wzdłuż północnego pojedyncza. Przy wschodnim krańcu miasta, od strony południowej przylegał aneks o wym. 80 na $40 \mathrm{~m}$, co nadawało całemu założeniu kształt zbliżony do litery L.

Znakomitym przykładem regularnej morfologii miejskiej było Kahun - duże osiedle z czasów Średniego Państwa (20I0-I630 p.n.e.), leżące koło współczesnej miejscowości al-Lahun, przy wejściu do oazy Fajum ${ }^{6}$. Jego położenie przy dolnej świątyni piramidy Senusereta II (I872-I853/52 p.n.e.) sugeruje, że było to dużych rozmiarów miasto piramid. Zajmowało ono obszar blisko I3 ha, na planie niemal kwadratowym. Regularny układ wewnątrz murów jest zdecydowanie bardziej dopracowany niż we wcześniejszych tego typu osiedlach. Tym samym jest to najbardziej reprezentatywny przykład egipskiego planowania na zasadzie regularnej siatki ulic. Daje się zauważyć nie tylko regularny przebieg ulic, ale także podział miasta na dzielnice, który odzwierciedlał jego strukturę społeczną. Północną część (od strony dobrego wiatru) zajmowały domy urzędników, po stronie zachodniej (strona złego wiatru) było osiedle robotników, resztę zaś stanowiła dzielnica urzędników niższego szczebla oraz rzemieślników i innych.

\footnotetext{
4 Ogólnie na temat miast piramid: R. Bussmann, Siedlungen im Kontext der Pyramiden des Alten Reiches, „Mitteilungen des Deutschen Archäologischen Instituts, Abteilung Kairo”, 60/2004, s. 17-39.

5 Chentkaus (I) żona Szepseskafa króla z IV dynastii, matka królów Sahure i Neferikare; zob. E. Otto, Chentkaus, w: Lexikon der Ägyptologie, t. 1,Wiesbaden 1975, s. 930-932.

6 Nazwę Kahun temu osiedlu nadał w 1889 r. W. F. Petrie, jego odkrywca i badacz; W. M. F. Petrie, Illahun, Kahun, and Gurob, London 1891; The Ancient of el-Lahun, w: Lahun Studies, red. S. Quirke, Reigate 1998, s. 1-41; N. Moeller, The Archaeology of Urbanism in Ancient Egypt. From the Predynastic Period to the End of the Middle Kingdom, Cambridge 2016, s. 335-338.
} 
Jedna ze stolic starożytnego Egiptu, Teby (eg. Uaset), również stanowi dobry przykład kontynuacji zastosowania regularnego układu przestrzennego miasta z ortogonalną siatką ulic. Grecy nazwali Teby stubramnymi, a Egipcjanie widzieli w nich wzór dla każdego miasta i nazywali je po prostu Miasto7. Już w czasach Średniego Państwa Teby zajmowały rozległy obszar ok. I00o na $500 \mathrm{~m}$. Za panowania XVIII dynastii zbudowano nowe miasto w nowym miejscu, położonym niżej niż poprzednie ${ }^{8}$. Miało ono kształt trapezu (ok. 9 na $6 \mathrm{~km}$ ). Ortogonalna siatka ulic wyznaczała dzielnice, odzwierciedlając tym samym strukturę społeczną mieszkańców Teb.

Na terenie Mezopotamii najstarsze miasta powstały już w pierwszej połowie IV tysiąclecia p.n.e. Na przełomie IV i III tys. p.n.e. w dużym stopniu zurbanizowała się jej część południowa. Zdecydowanie słabiej było na północy. Nie tylko w dolinach Tygrysu i Eufratu, ale również w dolinie Dijali powstały wówczas miasta, które stanowiły efekt tzw. rewolucji miejskiej Sumerów. Miasta z owalnym obrysem murów (granic) zajmowały powierzchnię od 50 do IOO (a nawet nieco więcej) hektarów. W niektórych z nich pojawił się pewien element układu prostokątnego. Są to cytadele zajmujące centralną część miasta. Istniały na przykład w Ur, jednym z głównych miast Sumeru, portowym mieście nad Zatoką Arabską . Pomimo tak dynamicznej urbanizacji, w Mezopotamii dość późno pojawia się miasto na planie czworoboku z w miarę regularną siatką ulic. Miało to bowiem miejsce dopiero w okresie neoasyryjskim (934-6I2 p.n.e.). Jednak znanych jest niewiele przykładów. Z jeszcze późniejszego czasu, bo z okresu chaldejskiego, pochodził Babilon, który stanowił najlepszy przykład regularnego założenia miejskiego dla terenów Międzyrzecza.

Najbardziej modelowe dla Mezopotamii miasto na planie prostokąta stanowił Dur Szarrukin (ob. Chorsabad, ok. $20 \mathrm{~km}$ na północ od Niniwy - Küyündżyk). Miasto założył na pniu król asyryjski Sargon II w latach 7I7-707 p.n.e. Było jego siedzibą i stolicą imperium asyryjskiego. Gruby podwójny mur ceglany o długości I750 x I650 m otaczał miasto, nadając mu regularny prostokątny obrys ${ }^{10}$. Do jego wnętrza prowadziło siedem bram, flankowanych lamassu. Głównym elementem urbanistyki Dur Szarrukin była dzielnica królewska, niejako nasadzona pośrodku północnej linii muru miejskiego. Był to typowy dla miast asyryjskich rodzaj ekal maszarti, z tym że bardzo rozbudowany, zawierający pałac królewski oraz inne budynki państwowe. Pałac, wzniesiony na wysokim podium, ewidentnie dominował nad miastem i wykorzystywał efekty widokowe krajobrazu, co nie było dotąd powszechnym zjawiskiem w Mezopotamii. Prace wykopaliskowe rozpoczęte w Chorsabadzie już w latach czterdziestych XIX w. skupiły się na reprezentacyjnej architekturze i sztuce, stąd nieznany jest przebieg ulic i zabudowa mieszkalna miasta Dur Szarrukin. Nadal wiedza o tym ważnym mieście pozostaje niepełna. Zresztą jego świetność też nie trwała długo. Następca Sargona II, Sennaherib (704-68I p.n.e.) rezydował w Niniwie, a Dur Szarrukin straciło na znaczeniu, stając się jedynie stolicą prowincji o tej samej nazwie.

Inny modelowy przykład mezopotamskiego miasta regularnego, choć odbiegający od omówionego wyżej Dur Szarrukin, to Babilon okresu chaldejskiego (626-539 p.n.e.). Wówczas

\footnotetext{
C. F. Nims, Thebes of the Pharaohs: pattern for every city, London 1965, s. 69.

8 Starsze miasto zostało wysiedlone, a na jego miejscu wzniesiono świątynie.

9 S. Pollock, Ur, w: The Oxford Encyclopedia of Archaeology in the Near East, red. E. M. Meyers, Oxford, New York 1997, s. 288-291.

10 P. Albenda, Dur-Sharrukin, the royal city of Sargon II, King of Assyria, "Bulletin of the Canadian Society for Mesopotamian Study", 39/2003, s. 5-13.
} 
było to największe miasto Bliskiego Wschodu i niewątpliwie jedno z największych na świecie. Zajmowało powierzchnię 850 ha. Wygląd Babilonu jest znany nie tylko dzięki wieloletnim badaniom archeologicznym, ale również dzięki znakomitemu opisowi Herodotosa, który grecki historyk zawarł w pierwszej księdze Dziejów (I78-I87). Miasto na planie prostokąta leżało po obu brzegach Eufratu. W każdej z dwóch części miasta główne ulice krzyżowały się pod kątem prostym ${ }^{\text {II }}$.

\section{Miasto idealne w świecie greckim}

Urbanistyka starożytnej Grecji, części kontynentalnej, wysp czy wybrzeży anatolijskich, jest dobrze rozpoznana i przebadana (łącznie z koloniami śródziemnomorskimi i nadczarnomorskimi). Zarówno w okresie mykeńskim (XVII-XII w. p.n.e.) jak i archaicznym (VIII-VI w. p.n.e.) powstawały liczne miasta i dynamicznie się rozwijały. Nie były jednak jednolite pod względem obrysu granic i morfologii, rozwijały się bowiem w sposób naturalny, niejako ewolucyjny. Ten rodzaj urbanistyki Grecy nazywali archaioteros tropos. Przemyślane planowanie miasta zaczęło się w świecie greckim dopiero z działalnością Hippodamosa z Miletu (ok. 498-408 p.n.e. ${ }^{\mathrm{I} 2}$. Jednak najlepszym, chciałoby się powiedzieć, planistą miasta $\mathrm{W}$ antyku wydaje się być Vitruvius - Rzymianin. Ten ostatni dał wiele wskazówek teoretycznych, ale sam raczej niczego nie zaplanował. Inaczej było z Hippodamosem. Ów Milezyjczyk nie tylko że zaplanował dwa lub trzy miasta, ale również przedstawił propozycję idealnej organizacji greckiej polis $^{13}$. Swoją koncepcję regularnego układu przestrzennego miasta zrealizował już w 479 r. p.n.e., odbudowując Milet, zniszczony w czasie powstania jońskiego. Kilkadziesiąt lat później, na zlecenie Periklesa, przebudował (około połowy V w. p.n.e.) Pireus, stosując (podobnie jak w Milecie) układ ortogonalny i swoją koncepcję podziału miasta. W $440 \mathrm{r}$. p.n.e. zaplanował i zrealizował założenie greckiej kolonii (apoikia) Thurioi na Półwyspie Apenińskim, nad Zatoką Tarencką (Wielka Grecja), w której spędził resztę swojego życia. Ostatnim dziełem Hippodamosa, wykonanym pod sam koniec życia, było najprawdopodobniej zaplanowanie miasta Rodos na wyspie o tej samej nazwie.

Podstawą urbanistyki Hippodamosa był podział miasta na sektory, łączone ulicami krzyżującymi się pod kątem prostym. Taki plan nazwano siatką hippodamejską ${ }^{\mathrm{I} 4}$. To właśnie na ten przemyślany podział miasta na sektory zwrócił uwagę Aristoteles ${ }^{15}$. Centralny sektor z główną agorą przeznaczony był na siedziby urzędów państwowych, inny (akropolis) to sektor instytucji religijnych, jeszcze inne mieściły gimnazja i teatry. Obiekty te musiały znajdować się w każdym mieście greckim od V wieku p.n.e. i stały się wręcz kanonicznym wyposażeniem miast hellenistycznych. Wreszcie pozostałe były dzielnicami mieszkalnymi, czyste, pozbawione zabudowy użyteczności publicznej, agor czy ogrodów. Proste, krzyżujące

\footnotetext{
11 Na temat urbanistyki i zabudowy Babilonu: I.L. Finkel, M.J. Seymur, Babylon, Oxford University Press 2009.

12 Hippodamos, w: The Macmillan Encyclopedia of Architects, red. A. Placzek, New York 1982.

13 Termin polis ma dość szerokie znaczenie w jęz. i kulturze greckiej. Oznacza nie tylko miasto w sensie formy urbanistycznej, ale również ustrój państwa charakterystyczny dla społeczeństwa greckiego począwszy od VIII w. p.n.e. W okresach archaicznym, klasycznym i hellenistycznym kształt tego ustroju był różny, właściwy dla każdej epoki. W jęz. polskim ciekawy na ten temat jest szkic: Ewy Wipszyckiej, O państwie, które państwem nie było, czyli o „polis” starożytnych Greków, w: E. Wipszycka, O starożytności polemicznie, Warszawa 1994, s. 18-29.

14 A. Burns, Hippodamos and the Planned City, "Historia: Zeitschrift für Altgeschichte", 25/1976, s. 414-428.

15 Arystoteles, Polityka, tłum., słowem wstępnym i koment. opatrzył L. Piotrowicz, wstępem poprzedził M. Szymański, Warszawa 2004, s. 60-63.
} 
się pod kątem prostym, ulice nie były zapewne wymysłem samego Hippodamosa. Mogły stanowić efekt zapoznania się Greków z urbanistyką egipską, jeszcze w VII w. p.n.e. Ulice te wyznaczały działki budowlane (insulae) o powierzchni $2400 \mathrm{~m}$ kwadratowych, na których wznoszono dwukondygnacyjne budynki mieszkalne. Miasto hippodamejskie nie musiało mieć regularnego obrysu linii granicznych, ale musiało być regularne wewnątrz. Był to bowiem podstawowy aspekt greckiego miasta idealnego. Tę odsłonę urbanistyki Grecy nazwali neoteros tropos.

Nowatorstwo w rozplanowaniu miast zastosowane przez Hippodamosa przy odbudowie Miletu z jednej strony było jego dziełem autorskim, z drugiej zaś stanowiło podsumowanie i kwintesencję dotychczasowej urbanistyki wschodniego regionu Morza Śródziemnego ${ }^{16}$. Punkt ciężkości Miletu przeniesiony został w stronę dwóch półwyspów wbijających się w zatokę ujścia Meandra. Tym samym nowe miasto zerwało łączność z dawną, jeszcze pamiętającą czasy mykeńskie, Akropolis. Naturalny podział półwyspu milezyjskiego wymusił podział miasta na trzy miejskie dzielnice różnej wielkości. Zdecydowana większość ulic miała 4-4,5 m szerokości. Natomiast kilka głównych było szerokich na 7,7-8,5 m. Również wielkość insulae nie była jednakowa i zależała od dzielnicy. Przeciętna insula stanowiła prostokąt o wymiarach 29,5 na 5I,5 m i dodatkowo była dzielona na trzy mniejsze działki pod zabudowę mieszkalną. Place (agory) oraz budowle użyteczności publicznej ściśle wkomponowano w całość założenia urbanistycznego. Wśród nich zdecydowanie wyróżniała się agora południowa (I64 na I96 m), otoczona portykami w porządku doryckim.

Jednak uwagę Aristotelesa w kontekście działalności Hippodamosa zwróciła nie urbanistyka pod względem formalnym, lecz zaproponowane przez niego planowanie organizacji społecznej polis ${ }^{17}$. Wielki filozof był oburzony tym faktem, gdyż Hippodamos, nie będąc mężem stanu, nie miał podstaw do takich propozycji. Według Hippodamosa polis powinno zamieszkiwać dziesięć tysięcy ludzi (nie mniej i nie więcej). Stanowili oni trzy grupy obywateli (polites) - wojownicy, rzemieślnicy i rolnicy. Dla każdej grupy wyznaczone zostało właściwe miejsce (dzielnica) w mieście. To właśnie ten aspekt działalności Hippodamosa został ostro skrytykowany przez Aristotelesa. Mimo to urbanistyka hippodamejska rozpowszechniła się nie tylko w świecie greckim, ale również w imperium rzymskim, by wreszcie od połowy XII wieku na dobre zakorzenić się w zaalpejskiej Europie.

W drugiej połowie IV wieku p.n.e. koncepcje urbanistyczne Hippodamosa kontynuował i rozwijał Deinokrates pochodzący najpewniej z Rodos (nieznane są dokładne lata życia) ${ }^{18}$. Pracował przede wszystkim dla Aleksandra Wielkiego. Zaproponował mu wybudowanie miasta na Górze Athos, ale król macedoński zamiar ten odrzucił, gdyż miasto w tym miejscu nie miałoby odpowiedniego zaplecza rolniczego. Jednak w 332 r. p.n.e. Deinokrates przystąpił

\footnotetext{
16 Milet został zniszczony przez Persów w czasie powstania jońskiego, a odbudowany według projektu Hippodamosa po roku 479 p.n.e.; H. J. Gehrke, Zur Geschichte Milets in der Mitte des 5. Jahrhunderts v. Chr., „Historia”, 29/1980, nr 1, s. 17-31; S. G. Patronos, Public Architecture and Civic Identity in Classic and Hellenistic Ionia. The Case of Miletus and Priene, Oxford 2002, s. 45-68.

17 J. C. Hogan, Hippodamus on the Best Form of Government and Law, "The Western Political Quarterly", 12/1959, nr 3, s. 763-783.

18 Ciekawym i kompleksowym opracowaniem na temat twórczości Deinokratesa jest: „Deinoctares of Rhodes” na stronie internetowej Technology Museum of Thessaloniki (www.tmth.edu.gr, dostęp: 15.12.2006).
} 
do realizacji planu Aleksandrii egipskiej, położonej pomiędzy brzegiem Morza Śródziemnego a jeziorem Mareotis. Również tu został wdrożony plan hippodamejski ${ }^{19}$.

Dążenia miast greckich do formy idealnej najlepiej widać na przykładzie miast hellenistycznych. Niemal wszystkie nowo powstające w ostatniej ćwierci IV i głównie w III w. p.n.e. miasta miały morfologię regularną według siatki hippodamejskiej.

Dobrym przykładem urbanistyki typu neoteros tropos jest Olint na półwyspie Chalkidiki. Ta ateńska apoikia została zdobyta i zburzona do fundamentów w 348 r. p.n.e. przez Filipa II, króla macedońskiego. Odbudowa w nowej formie nastąpiła zapewne pod koniec IV w. p.n.e. i może była związana z działalnością Kassandra ${ }^{20}$. W tym przypadku ideał hippodamejski został jeszcze bardziej dopracowany. W morfologii Olintu daje się zauważyć nieco nowszą (w stosunku do Hippodamosa) koncepcję urbanistyczną. Ortogonalny układ ulic i zabudowy dostosowany został do stron świata i panującego w mieście klimatu. W ten sposób „odpowiednio" wiatr wiał w każdej porze roku i właściwy był również stopień nasłonecznienia (na to uwagę trzy wieki później zwrócił Vitruvius). W Olincie zastosowano trzy szerokości ulic. Najszersze to drogi tranzytowe o szerokości $7 \mathrm{~m}$, biegnące co ok. 86,5 m w układzie południkowym. Nazwano je plateiami (plateiai) Nieco węższe były lokalne ulice miejskie (przecznice) o szerokości $5 \mathrm{~m}$ i biegnące w odstępach $35,5 \mathrm{~m} \mathrm{w}$ układzie południkowym. Te nazwano stenopami (stenopoi). Najwęższe to ulice o szerokości $2 \mathrm{~m}$, które można byłoby określić mianem „osiedlowych”. One zaś ułożone były równoleżnikowo. Po raz pierwszy w urbanistyce greckiej spotyka się tego typu ulice, przeznaczone do obsługi zabudowy mieszkalnej. Ulice tranzytowe ciągnęły się wzdłuż węższych (wschodnich i zachodnich) boków insulae. Takie rozróżnienie spowodowane było natężeniem ruchu, ale równocześnie samoistnie regulowało owo natężenie. Na ulicach południowych i północnych panował zdecydowanie mniejszy ruch, a tym samym mieszkańcy mieli większy spokój od tej strony. Insulae były prostokątami podzielonymi ulicami osiedlowymi na dwie części o szerokości I6,75 m. Każda z nich dzieliła się jeszcze na pięć jednakowych działek o powierzchni $290 \mathrm{~m} \mathrm{kw}$. Działki te mogły być albo dzielone na mniejsze, albo łączone w większe, w zależności od potrzeb.

Od początku III w. p.n.e. nowy typ urbanistyki bardzo się upowszechnił w Azji poza regionem śródziemnomorskim. Dotyczyło to zarówno wielkich miast królewskich, jak i niewielkich ośrodków prowincjonalnych. Przykładem tych ostatnich może być choćby Dura Europos nad Eufratem, miasto powstałe ok. 300 r. p.n.e. Jego ortogonalny układ tworzyło dwanaście prostych ulic w linii północ - południe i dziewięć na kierunku wschód - zachód. Tak przebiegające ulice (o szer. 6, 8,5 a nawet $\mathrm{I} 2,5 \mathrm{~m}$ ) tworzyły insulae o wymiarach 35 na $70 \mathrm{~m}^{2 \mathrm{I}}$. Agora miała pierwotnie zajmować obszar ośmiu, a ostatecznie zajęła aż czterech insulae.

Przy okazji omawiania miast azjatyckich godny odnotowania jest przypadek Pergamonu. Było to ważne miasto w Anatolii, znaczący ośrodek polityczny i kulturalny, królewskie miasto

\footnotetext{
19 Aleksandria hellenistyczna nie jest jeszcze w pełni poznana, mimo wieloletnich prac archeologicznych, zdecydowanie lepiej znana jest z czasów rzymskich; K. Michałowski, Aleksandria, Warszawa 1970; B. Tkaczow, Aleksandria. Najjaśniejsza, Najpiękniejsza, Najświetniejsza, Warszawa 1988; taż, Topography of Ancient Alexandria (An Archaeological Map), Warszawa 1993; G. Grimm, Alexandria. Die Erste Königsstadt der hellenitischen Welt, Mainz am Rhein 1998; A. Łukaszewicz, Egipt Greków i Rzymian, Warszawa 2006, s. 358-381.

20 Na temat historii, urbanistyki, zabudowy oraz gospodarki i życia społecznego: rozdz. II History and Archaeology at Olynthus, w: N. Cahill, Household and City Organization at Olynthus, Yale University Press 2008, s. 25-40, www.stoa.org (dostęp: 30.09.2018).

21 Działki o tak wydłużonej formie były cechą charakterystyczną dla miast fundowanych przez Seleukidów.
} 
Attalidów ${ }^{22}$. Mimo to nie zastosowano w jego morfologii układu ortogonalnego. Uzasadnienie tego faktu nie jest skomplikowane - ukształtowanie terenu nie dawało takich możliwości. Z drugiej jednak strony Pergamon, choć pod względem formalnym nie był idealny, to miał jeden element, który dawał mu przewagę nad miastami hippodamejskimi. Była to możliwość stosowania w zabudowie rozwiązań monumentalnych. Ten nieregularny, a może dla niektórych nawet chaotyczny obraz urbanistyki i architektury Pergamonu, był jednak przemyślany i nieprzypadkowy. Jego twórcy znakomicie wykorzystali warunki terenowe. I dla tej specyficznej formy zrobili to wręcz idealnie. W dominujących nad otoczeniem punktach wzniesiono świątynie i pałac królewski. Na zboczach wzgórz posadowiono budynki publiczne, a na niżej położonych tarasach znalazła się zabudowa mieszkalna. Tym samym Pergamon wypracował swoistą, tylko dla siebie możliwą do realizacji formę urbanistyczną. Można powiedzieć, że w taki sposób to miasto dążyło do osiągnięcia idealnej formy urbanistycznej.

Warto zwrócić jeszcze uwagę na plan Selinuntu (gr. Selinus), kolonii greckiej na Sycylii. Założyli ją koloniści z Megary Hyblaea ok. 628 r. p.n.e. Pod koniec V w. p.n.e. zniszczony został przez Kartagińczyków i wkrótce odbudowany. W połowie III w. p.n.e. ostatecznie przez nich zniszczony ${ }^{23}$. Miasto obrysem granic przypomina gruszkę. W południowej części znajdowała się Akropolis z kilkoma świątyniami. Regularność morfologii reprezentowała północna część miasta. W rozplanowaniu Selinuntu występuje jeszcze ciekawsza gradacja ulic (głównych i drugorzędnych) niż w Olincie. Wyraźnie daje się zauważyć szeroka główna ulica, biegnąca z północy na południe, czyli plateia. Była to jedyna w tym mieście tego typu arteria. Przecinały ją pod kątem prostym drugorzędne ulice, biegnące równoleżnikowo (stenopoi). Do takiego układu ulic dostosowano położenie świątyń miejskich, usytuowanych w obrębie Akropolis ${ }^{24}$.

Nie tylko Selinunt stanowił na Sycylii przykład regularnego morfologii miasta. Na terenie Wielkiej Grecji podobny układ miały Metapunto czy Megara Hyblaea (z VI w. p.n.e.) ${ }^{25}$.

\section{Miasto idealne w świece rzymskim}

W świecie rzymskim działał najbardziej znany urbanista starożytności, czyli Vitruvius. Jego teoretyczne dzieło De architectura libri decem jest do dnia dzisiejszego znakomitym źródłem do historii bardzo szeroko pojętej architektury antycznej, w tym także urbanistyki. Co ciekawe, o samym autorze nie da się wiele powiedzieć, także jego traktat nie jest znany w całości ${ }^{26}$. Nie jest pewne, czy zrealizował jakiś swój projekt budowlany, czy pozostał jedynie teoretykiem, ale bardzo dobrze obeznanym z problematyką architektury, budownictwa i urbanistyki. Dla Vitruviusa przy zakładaniu nowego miasta najważniejsze były uwarunkowania zdrowotne

\footnotetext{
22 Pergamon, w: C. McEvedy, Cities of the Classical World. An Atlas and Gazetteer of 120 Centres of Ancient Civilizations, Penguin Global 2012, s. 230.

23 Zob. hasło Selinus, w: International Dictionary of Historical Places, t. 3: Southern Europe, Fitzroy Dearborn Publishers 1995, s. 634-640.

24 Ciekawe studium na ten temat: Th. M. Grupico, The Influence of Urban Planning on Temple Design in West Greece, New Brunswick 2008, s. 17-19 (dot. Selinuntu).

25 L. Sardo, Verso il canone Della Polis, w: Lacittà greca antica: istituzioni, società e forme urbane, red. E. Greco, Roma 1999, s. 85-87.

26 Marcus Vitruvius Polio ur. się pomiędzy 80 a 70 r. p.n.e. i zmarł najpewniej pod sam koniec I w. p.n.e.: na temat życia Vitruviusa i jego traktatu zob. A. Sadurska, Witruwiusz i jego dzieło, w: Witruwiusz, O architekturze ksiag dziesięć, thum. K. Kumaniecki, Warszawa 2004, s. 5-22; B. Baldwin, The Date, Identy, and Career of Vitruvius, "Latomus", 4/1990, s. 425-434; Th. G. Smith, Vitruvius on Architecture, New York 2004.
} 
w odniesieniu do jego przyszłych mieszkańców (np. problem wody, bagien, położenia w stosunku do kierunku wiatrów wiejących w danym regionie), a w dalszej kolejności, ekonomiczne i obronne ${ }^{27}$. Poświęcił tym zagadnieniom trzy rozdziały w Księdze pierwszej swojego traktatu. W rozdziale siódmym tej samej księgi zajął się natomiast rozplanowaniem samego miasta, idealnie założonego według jego wskazówek. W tym miejscu przejawem ideału powinna być wygoda mieszkańców. Dla przykładu: w miastach nadmorskich forum powinno być położone jak najbliżej portu. W innych przypadkach musi znajdować się w centrum miasta ${ }^{28}$. W praktyce urbanistyki rzymskiej nie zawsze stosowano się do tych wskazówek.

Miasta w imperium rzymskim reprezentowały różne typy urbanistyczne. Było to konsekwencją podporządkowywania sobie regionów zróżnicowanych pod względem urbanistycznym. Podobnie jak w przypadku Grecji i Wschodu, również dla Rzymian idealną morfologią miasta był regularny układ przestrzenny. Rzym odziedziczył ją zarówno od Etrusków (np. Marzabotto) jak i od Greków z Wielkiej Grecji. Dla tych pierwszych porządek miasta stanowił odbicie porządku kosmicznego. Było to zwłaszcza widoczne w obrzędach założenia miasta, które przejęli później Rzymianie. Wyznaczenie granicy pomoerium czy podział wnętrza miasta na cztery części przez przecinające się w centrum dwie główne ulice: cardo (oś północ - południe) i decumanus (oś wschód - zachód), stanowiły jego egzemplifikację. Ale Rzym wypracował także własny plan miasta, co prawda w pewnym nawiązaniu do starszej tradycji. Był to plan castrum romanum, czyli wojskowego obozu rzymskiego. Zwłaszcza odnosi się to do castrum stativum (obóz stały), który można uznać za swoistą formę urbanistyczną (niczym miasta piramid w Egipcie). W tym przypadku położenie i rozplanowanie obozu warunkowało, co jest oczywiste, kilka czynników. Z czasem wokół tych obozów powstawały osady (canabae; burgi), które wraz z obozem dały początek wielu europejskim miastom, głównie poza regionem śródziemnomorskim ${ }^{29}$.

Na terenie Italii najstarszymi przykładami regularnego układu przestrzennego miasta są: Marzabotto i Pompeje. Ciekawe zwłaszcza jest to pierwsze miasto. Marzabotto, dziś w ramach aglomeracji bolońskiej, w starożytności rozwijało się w dwóch fazach jako miasto etruskie: (I) - pomiędzy 550 a 500 p.n.e. i (2) - V w. p.n.e. W drugiej fazie nosiło zapewne nazwę Kainua, prawdopodobnie wywodzącą się od greckiego kalvó (,„nowy”), co mogło nawiązywać do nowej fazy w funkcjonowaniu miasta ${ }^{30}$. Interesujące jest to, że miasto założone zostało na planie bardzo podobnym do planu Selinuntu (z terenu Wielkiej Grecji). Oś całego założenia wyznaczała ulica biegnąca z północy na południe. W trzech miejscach krzyżowały się z nią ulice biegnące ze wschodu na zachód. Te cztery ulice można uznać za plateiai, które dzieliły miasto na dzielnice (regiones). Mniejsze obszary zabudowy wyznaczały stenopoi łączące ulice biegnące równoleżnikowo. Tym samym widać w morfologii Marzabotto wczesny przejaw nowszej myśli urbanistycznej, najprawdopodobniej zaczerpniętej od Greków z południowej Italii i Sycylii ${ }^{31}$.

\footnotetext{
27 Witruwiusz, O architekturze..., I, 4-6.

28 Tamże, I, 7, 1 .

29 Takim właśnie przykładem jest Neuss na Renem. Najstarszy obóz castrum stativum założony został pomiędzy 20 a 15 rokiem n.e. jako Novaesium. Jest on również przykładem obozu wręcz modelowego; na temat Neuss zob. J. Franssen, Castrum Novaensium, w: Novaensium, allias Neuss, www.novaesium.de (dostęp: 21.08.2010).

30 R.A.Staccidi, Gli Etrisch. Un popolo tra mito e realtà, Newton Compton Editori 2005, s. 186-187.

31 Kompleksowo na temat dziejów i urbanistyki Marzabotto zob. Marzabotto una città etrusca, red. E. Govi, Ante Quem 2007.
} 
Drugi wzorzec miasta rzymskiego stanowiło castrum romanum. Z jednej strony były one reprezentacyjnymi siedzibami garnizonów rzymskich, z drugiej fortecami strzegącymi granic (limes) lub punktów strategicznych. Ich długoletnia obecność na danym terenie sprawiła, że stawały się zaczątkami miast, notabene na terenach dotąd niezurbanizowanych.

Castrum zakładano na planie prostokąta (czasem kwadratu), niekiedy o zaokrąglonych narożnikach ${ }^{32}$. Układ urbanistyczny obozu wytyczały ulice: via praetoria (pn.-pd.) oraz via principalis (wsch.-zach.). Ta druga łączyła dwie bramy boczne (porta principalis dextra i porta principalis sinistra). Via quintana biegła równolegle do via principalis, lecz nie łączyła żadnych bram. Dookoła obozu (wewnątrz), wzdłuż umocnień biegła via sagularis (zachowana także miastach; w Polsce średniowiecznej to ulica Wałowa obecna w bardzo wielu miastach). Główną bramę obozu stanowiła brama północna (porta praetoria) i tak było również w miastach wzorowanych na planie obozu. Ulice dzieliły wnętrze obozu na kilka sektorów. Praetendura była to część od bramy północnej do via principalis. Centrum obozu stanowiły latera praetori, a od via quintana do porta decumana (brama południowa) znajdowała się retendura. W wielu castrach znajdowały się obiekty niejako typowo miejskie: sklepy, termy, veletudinaria (szpitale) czy veterinaria (lecznice dla zwierząt). Przemyślane i uporządkowane rozplanowanie obozów wojskowych sprawiło, że stanowiły one znakomity wzorzec dla idealnej morfologii miasta.

Jednym z najstarszych znanych obozów jest Castra Vetera, czyli Xanten w Nadrenii. Założył go Augustus w I5 r. p.n.e., a przebudował Nero. W jego planie widać obowiązującą jeszcze wówczas zasadę (zalecaną także przez Higinusa) założenia głównej ulicy obozu na linii zachód - wschód ${ }^{33}$. Odejście od tej zasady widać w castrum w Lambaesis w centrum Numidii (ob. Algieria), założonym przez Hadrianusa ${ }^{34}$. Warte wspomnienia jest także inne miasto północnoafrykańskie - Timgad (dziś w Algierii). Założył je około roku Ioo n.e. Traianus. Ulicę przelotową stanowiła tu via principalis (zach.-wsch.). Przy jej skrzyżowaniu z via pretoria (biegnącej od bramy północnej tylko do centrum miasta/obozu) znajdowało się forum, a na południe od niego - teatr.

Niestety, jak w przypadku wielu znaczących miast śródziemnomorskich, również w Rzymie nie został zastosowany plan regularny. Tym samym stolica imperium nie była miastem idealnym pod względem morfologii.

Na koniec warto jeszcze zwrócić uwagę na inne regiony Wschodu. Otóż regularny układ przestrzenny miasta jako forma idealna nie stanowił specyfiki jedynie Śródziemnomorza. Obecny był bowiem także w Azji południowej i na Dalekim Wschodzie. W Indiach zakładano miasta o prostokątnym obrysie granic i siatce ulic przecinających się pod kątem prostym. Zasada ta znalazła wytłumaczenie w Traktacie Manasara z V-VII w. n.e.35. To

\footnotetext{
32 Interesującym źródłem pisanym do rozplanowania obozu rzymskiego jest De Munitionibus Castrorum (O wytyczaniu obozów wojskowych). Wcześniej dzieło to przypisywano Hyginusowi Gromaticusowi (I w. n.e.), lecz dziś autora tego traktatu określa się jako Pseudo-Hyginus i datuje się jego powstanie na początek II w. n.e. (są i późniejsze datacje, np. na pocz. IV w. n.e.); zob. Wstęp, w: Pseudo-Hyginus, O wytyczaniu obozów wojskowych, tłum. i oprac. I. Łuć, K. Królczyk, Poznań 2010, s. 7-11.

33 Dobrym opracowaniem tego obozu (choć sprzed kilkudziesięciu lat jest: H. von Petrikovitz, Vetera, w: Pauly's Realencyklopädie der klassischen Alterumswissenschaft, Neue Bearbeitung, wyd. 2, t. 8, Stuttgart 1958, kol. 1801-1834 .

34 Zob. T. Kotula, Afryka Pótnocna w starożytności, Wrocław 1972, s. 412-413.

35 Szczególnie w rozdziałach IV, VII i X: Architecture of Mānasāra (Original Sanskrit Text with English Translation and Notes, tłum. Prasanna Kumar Acharya, red. N.C. Panda, Bkaratiya Kala Prakashan 2011, s. 18-22, 47-86,
} 
ważny tekst w ramach wastu śastra (vāstu śāstra), czyli staroindyjskiego systemu architektonicznego. W jego ramach miejsce, wymiary czy geometria przestrzenna miały znaczenie fundamentalne. W Chinach już w czasach panowania dynastii Zhou (ok. IO45-256 p.n.e.) uważano za ideał miasto założone na planie kwadratowym o długości boku prawie sześciu tysięcy metrów (czyli dziewięciu li) i ulicach przecinających się pod kątem prostym. Tradycja ta przetrwała wiele wieków. Jeszcze w XII w. n.e. (czasy panowania dynastii Song: 960-I279 n.e.) powstał chiński traktat na temat regularnego założenia miejskiego z regularną morfologią, autorstwa Li Min $\mathrm{Zhou}^{36}$.

\section{Podsumowanie}

Z przedstawionych wyżej przykładów morfologii miast w basenie Morza Śródziemnego łatwo wynuć wniosek, że regularny układ przestrzenny stanowił ideał, który zdominował ówczesną myśl urbanistyczną. Nie ulega wątpliwości, że dla regionów śródziemnomorskich taka forma morfologii miasta narodziła się w Egipcie i najpierw za pośrednictwem Jonii w VI w. p.n.e., a następnie Hippodamesa z Miletu w V w. p.n.e., rozprzestrzeniła się w całym Śródziemnomorzu. Regularny układ przestrzenny dawał najlepsze możliwości funkcjonowania miastu i jego mieszkańcom, ale był również łatwy do realizacji. Nawet obozy wojskowe armii rzymskiej zaadaptowały ten model. W Indiach i Chinach taka morfologia miejska została zaopatrzona w szczegółowe uzasadnienie filozoficzne.

Europa nie porzuciła całkowicie planu miasta regularnego. Sięgnęła po sprawdzony model idealny w chwili odradzania się urbanistyki europejskiej w nawiązaniu do tradycji antycznej w XII-XIII w. (n.e.). Można w tym miejscu przywołać choćby villes bastidea: Montauban, Monpazier czy Mirande. Ich wzór jako villes neuves od XIII w. (n.e.) stały się podstawowym wzorem miast zakładach w Europie Zaalpejskiej, także na ziemiach polskich.

\section{Ancient towns in the Mediterranean - in search of the ideal form}

\section{Abstract}

Undoubtedly, one of the greatest achievements of antiquity in the Mediterranean basin is the origin and development of the city in a very broad sense; not only as the functional human settlement, but also the idea that found its place in philosophy. This article is a synthetic discussion of ancient Mediterranean urban planning in terms of its search of the ideal form of the city. Already in Mesopotamia and Egypt in the 4th - 3rd millennium BC they began to "experiment" with the layout of a functional and convenient city for its residents. However, only in the Greek and then Roman world did the ideal form find its full realization. It was then that the most representative examples of the ideal city were created.

Key words: history, antiquity, city, urban planning, Mediterranean Sea

150-163. Podobne traktaty spisywano również w późniejszych wiekach, VI i IX

${ }_{36}$ Q. Guo, Yingzo Fashi. Twelfth-Century Chinese Building Manual, "Architectural History: Journal of the Society of Architectural Historian of Great Britain", 41/1998, s. 1-13. 


\section{BIBLIOGRAFIA}

Albenda P., Dur-Sharrukin, the royal city of Sargon II, King of Assyria, "Bulletin of the Canadian Society for Mesopotamian Study", 39/2003, s. 3-I5.

Architecture of Mānasāra (Original Sanskrit Text with English Translation and Notes, tłum. Prasanna Kumar Acharya, red. N.C. Panda, Bkaratiya Kala Prakashan 201 .

Arystoteles, Polityka, tłum., słowem wstępnym i koment. opatrzył L. Piotrowicz, wstępem poprzedził M. Szymański, Warszawa 2004.

Bieliński P., Starożytny Bliski Wschód. Od początków gospodarki rolniczej do wprowadzenia pisma, Warszawa 1985.

Burns A., Hippodamos and the Planned City, "Historia. Zeitschrift für Alte Geschichte", 25/1976, s. 4I4-428.

Bussmann R., Siedlungen im Kontext der Pyramiden des Alten Reiches, „Mitteilungen des Deutschen Archäologischen Institut, Abteilung Kairo", 60/2004, s. I7-39.

Cahill N., Household and City Organization at Olynthus, Yale University Press 2008, www. stoa.org (dostęp: 30.09.20I8).

Deinoctares of Rhodes, Technology Museum of Thessaloniki, www.tmth.edu.gr (dostęp: I5.I2.2006).

Finkel I. L, Seymur M. J., Babylon, Oxford 2009.

Franssen J., Castrum Novaensium, "Novaensium allias Neuss", www.novaensium.de (dostęp: 2I.08.20IO).

Gehrke H. J., Zur Geschichte Milets in der Mitte des 5. Jahrhunderts v. Chr., "Historia", 29/1980, nr I, s. I7-3I.

Greaves A. M., Miletos, a History, London 2002.

Grimm G., Alexandria. Die Erste Königsstadt der hellenitischen Welt, Mainz am Rhein 1998.

Grupico Th. M., The Influence of Urban Planning on Temple Design in West Greece, New Brunswick 2008.

Guo Q., Yingzo Fashi. Twelfth-Century Chinese Building Manual, "Architectural History: Journal of the Society of Architectural Historian of Great Britain”, 4I/I998, S. I-I3.

Hippodamos, w: The Macmillan Encyclopedia of Architects, red. A. Placzek, New York I982, s. 232-234.

Hogan J. C., Hippodamus on the Best Form of Government and Law, "The Western Political Quarterly",I2/1959, nr 3, s. 763-783.

Kotula T., Afryka Pólnocna w starożytności, Wrocław 1972.

Łukaszewicz A., Egipt Greków i Rzymian, Warszawa 2006.

Marzabotto una città etrusca, red. E. Govi, Ante Quem 2007.

McEvedy C., Cities of the Classical World. An Atlas and Gazetteer of I20 Centres of Ancient Civilizations, Penguin Global $20 \mathrm{I} 2$.

Michałowski K., Aleksandria, Warszawa 1970.

Moeller N., The Archaeology of Urbanism in Ancient Egypt. From the Predynastic Period to the End of the Middle Kingdom, Cambridge 2016.

Nims C. F., Thebes of the Pharaohs: pattern for every city, London 1965.

Otto E., Chentkaus, w: Lexikon der Ägyptologie, t. I, Wiesbaden 1975, s. 930-932.

Patronos S. G., Public Architecture an Civic Identity in Classic and Hellenistic Ionia. The Case of Miletus and Priene, Oxford 2002. 
Petrie W. M. F., Illahun, Kahun, and Gurob, London I89I.

Petrikovitz von H., Vetera, w: Pauly's Realencyklopädie der klassischen Alterumswissenschaft, Neue Bearbeitung, wyd. 2, t. 8, Stuttgart 1958, kol. I80I-I834.

Pollock S., Ur, w: The Oxford Encyclopedia of Archaeology in the Near East, red. E. M. Meyers, Oxford, New York 1997, s. 288-29I.

Pseudo-Hyginus, O wytyczaniu obozów wojskowych, tłum. i oprac. I. Łuć, K. Królczyk, Poznań 20I0.

Reisner G. A., Wheeler N. F. Dunham D., Second Cataract Forts II. Uronarti, Shalfak, Mirgissa, Boston 1967.

Sadurska A., Witruwiusz i jego dzieło, w: Witruwiusz, O architekturze ksiag dziesięć, tłum. K. Kumaniecki, Warszawa 2004.

Sardo L., Verso il canone della polis, w: Lacittà greca antica: istituzioni, società e forme urbane, red. E. Greco, Roma I999, s. 85-87.

Selinus, w: International Dictionary of Historical Places, t. 3: Southern Europe, Fitzroy Dearborn Publishers 1995, s. 634-640.

Smits Th. G., Vitruvius on Architecture, New York 2004.

Staccidi R. A., Gli Etrisch. Un popolo tra mito e realtà, Newton Compton Editori 2005.

The Ancient of el-Lahun, w: Lahun Studies, red. S. Quirke, Reigate I998, s. I-44.

The Oxford History of Ancient Egypt, red. I. Shaw, Oxford 2000.

Tkaczow B., Aleksandria. Najjaśniejsza, Najpiękniejsza, Najświetniejsza, Warszawa I988.

Tkaczow B., Topography of Ancient Alexandria (An Archaeological Map), Warszawa 1993.

Vollkommer R., Deinokrates, w: Künstlerlexikon der Antike, red. R. Vollkommer, t. I, München-Leipzig 200I, s. I62.

Wipszycka E., O starożytności polemicznie, Warszawa 1994. 